\title{
From the Inertia Variations
}

\author{
John Tottenham
}

(C) The Author(s) 2010. This article is published with open access at Springerlink.com

\section{THE ARRIVAL}

For years on end I have been sitting here

Impatiently awaiting potency; some explosive revelatory surge

That will carry me away and permit no looking back.

But this moment of deliverance has not arrived,

And I have done nothing to hasten it.

Perhaps it doesn't matter.

Perhaps I wasn't meant to do anything:

In which case, I have succeeded admirably.

\section{ACCOMPLISHMENT}

It would be a relief if I could resign myself

To unproductivity and simply exist

Unburdened by this tiresome need to produce

That has been the cause of so much unpleasantness.

It's not as if I do anything with my time

And as for most of the people who do accomplish

Anything: one rather wishes they hadn't bothered either.

Accomplishment, I suspect, is overrated.

\footnotetext{
J. Tottenham ( $\square)$

Los Angeles, CA, USA

e-mail: otiosity@sbcglobal.net
} 


\section{CITADEL}

Am I empty at the core or just around the edges?

Are there riches therein? I wouldn't know.

I'm weighed down in a warm white glow,

Crushing the stark yellow dullness of the day

Into dust, statically and statelessly drifting

Throughout this haze of rust. Riding the waves

Of lostness across the landscape of a desk,

Into the bulwark of a threadbare curtain.

\section{LIFE WITHOUT WORK}

To do nothing

In this day and age,

When so much pointless work

Is being produced,

Could almost be considered an achievement.

It all compares most unfavorably

With my own imaginary

Body of work.

\section{PATRONAGE OF NEGATION}

I am constantly confronted by other people's works

That I could have created myself.

And I am constantly disappointed by them.

Sadly, I have to recognize them

For what they are: inferior versions

Of what I could have done

If I'd been insecure enough in my abilities

To do anything.

\section{TO POSTERITY}

My most profound observations

Have gone unrecorded. They were too subtle

And I was too lazy to pin them down.

I was always sluggishly scrambling

Onto the next thing that would remain undone

Or underdone. It was, of course, within my power

To formulate them, despite the fact

That no evidence of them exists. 
Open Access This article is distributed under the terms of the Creative Commons Attribution Noncommercial License which permits any noncommercial use, distribution, and reproduction in any medium, provided the original author(s) and source are credited. 